\title{
1. Introduction: The evolution of the economic analysis of corporate law
}

\author{
Claire A. Hill and Brett H. McDonnell
}

\section{INTRODUCTION}

Economic analysis plays a crucial role in contemporary scholarly writing on corporate law. Indeed, although doctrinal analysis remains important and other interdisciplinary perspectives can occasionally be seen, economic analysis dominates most current corporate law scholarship. Sometimes the economics involves formal mathematical modeling; increasingly frequently, it involves econometric data analysis, while even more frequently it takes a softer, more informal form. Still, whatever the form, there is usually some reliance on ideas drawn from economics.

Thus, a research handbook on the economics of corporate law is hard to distinguish from a research handbook on corporate law, period. And indeed, in this volume we have felt little need to try to make that distinction. The collected contributions give an overview of some of the leading lines of research that scholars today are pursuing in trying to understand and critique legal developments in corporate law.

This volume is part of a new series of Research Handbooks in Law and Economics, directed by Francesco Parisi and Judge Richard Posner. As the editors of an earlier volume said, '[e]ach volume in the series aims to serve as a reference, providing helpful introductions to important topics, and as a provocateur, suggesting weaknesses and important areas for further exploration.' (Farber \& O'Connell 2010,1)

We hope that several different audiences will find this volume useful. Scholars in the field can look to it for a useful gathering of leading research, and also for suggestions as to possible directions for further research. Students and scholars just starting on the path of research into corporate law can look to it for an introductory overview. Practitioners in the field may be curious what scholars are saying, and can find that brought together in a quick reference guide. Policymakers may find leads on ideas for reforms.

In this Introduction we give a quick historical overview of the economic analysis of corporate law as well a description of the book that follows. Part II sketches the origins of the economic analysis of corporate law. Part III sketches how that analysis has developed over the last two decades. Part IV gives an overview of this volume.

A caution: many persons have contributed to a vast scholarly body of work on corporate law. Even this not-thin volume cannot hope to be anything close to comprehensive. There are important areas of law and research that we do not address at all, and within the areas that are addressed, the chapters can only sample some of the leading contributions. Large amounts of extremely good work must go unmentioned. 


\section{ORIGINS OF THE ECONOMIC ANALYSIS OF CORPORATE LAW}

We can look for the origins of the economic analysis of corporate law within both economics and legal scholarship. Much of our current understanding of the core problems of the field go back to an early collaboration between a law professor and an economist: Berle and Means (1932). They identified the separation of ownership and control, with public corporations owned by a dispersed group of shareholders, none of whom owned enough shares to have the incentive to rigorously monitor managerial behavior. A problem thus arose as to what, if anything, keeps managers from exploiting corporate resources for their own ends - what economists call an agency problem. The key question for scholars has been how corporate law does and should regulate this agency problem.

For a long time, academic economists largely treated firms as a black box, not saying much about the incentive issues within firms. But gradually they developed a theory of the firm. Ronald Coase (1937) began by asking what explains the boundaries between transactions that occur within firms and transactions between firms. He pointed to different transaction costs of the two types of transactions, arguing that boundaries would adjust to minimize transaction costs.

Coase left the concept of transaction costs rather vague. A subsequent school of transaction cost economics began to fill in the gaps. Oliver Williamson $(1975,1985)$, the leader of this school, focused on asset specificity. Where investments in assets are much more valuable within specific relationships, firms are more likely to form. A related property rights approach formalized similar ideas, with a focus on who has the right to decide how particular assets are used (Grossman \& Hart 1986; Hart \& Moore 1990; Hart 1995).

A somewhat different line of research used agency theory and corporate finance to shape the theory of the firm. Alchian and Demsetz (1972) is a key early work in this line, but the most influential contribution is Jensen and Meckling (1976). Jensen and Meckling coined the idea of the firm as a nexus of contracts, which became extremely important to the application of economic ideas within the legal academy.

The modern application of economic thinking within corporate law scholarship started in the 1960s with several papers by Henry Manne $(1965,1967)$. Others began to contribute in the 1970s and 1980s, and the volume of papers accelerated. By the beginning of the 1990s, corporate law and economics had reached its mature initial form, with important books by Frank Easterbrook and Daniel Fischel (1991) and Roberta Romano (1993) summarizing the approach. Several features stand out in what one can call the Chicago School approach. It applied relatively basic microeconomic theory to an understanding of corporations and corporate law. Most of the work was theory, often informal (non-mathematical) theory, with relatively little empirical research (Romano was an important exception). The theory generally assumed strong individual rationality and well-functioning markets. It analyzed many ways in which markets effectively constrained managerial self-dealing. As a result, its normative tilt usually viewed strong regulations with skepticism. The approach painted most state corporate law as creating enabling default rules rather than mandatory regulations, and it approved. By the 1990s, this sort of economic theorizing dominated corporate law scholarship. 


\section{DEVELOPMENTS IN LAW AND IN ECONOMICS}

That scholarship has evolved significantly over the last two decades. Some of that evolution reflects responses to changes in the law and in corporate governance practices. Other parts of that evolution reflect changes within economic scholarship. We discuss each source of change in turn.

There have been many major developments in corporate law and corporate governance. One area that had already begun to evolve significantly in the 1980s as the first wave of economic analysis hit was the market for corporate control (Davidoff Ch. 12). Public corporations faced a wave of hostile takeover bids. Target management and their lawyers developed a variety of innovative defenses, and the courts needed to address legal changes to those defenses. Although Delaware courts attempted to craft a balanced approach, by the end of the 1980s they had left enough latitude for effective defenses that a well-advised board could generally ward off any direct hostile assault. But hostile overtures continue, and courts have continued over the last few decades to refine the legal standards developed in the 1980s.

The main way in which contemporary state corporate law attempts to police managerial misbehavior is via shareholder suits claiming breaches of fiduciary duty (Hill \& McDonnell Ch. 8; Thomas \& Thompson Ch. 9). Fiduciary duty law has evolved significantly in recent decades. Once there were just two main standards of judicial review: the duty of loyalty and the duty of care. But a variety of intermediate standards have arisen, many but not all in the change of control context. A particularly notable development has been the development of the law of good faith. Scholars have analyzed and debated this and other developments in fiduciary law.

A leading change has been the growth of institutional investors and shareholder activism (Smith Ch. 4; Ferri Ch. 11). Over half of the shares of American public corporations are now owned by institutions such as mutual funds, pension funds, and hedge funds. Some of these institutions have better incentives to become involved in corporate governance than the isolated small shareholders described in the Berle \& Means picture of the corporation. Simultaneously, the decline in the market for corporate control and the dim prospects for most fiduciary duty suits have, together, reduced the effectiveness of other forms of control. As a result, some institutional investors have sought to become actively involved in corporate governance matters, and to change the law to make it easier to do so. Some corporate scholars have applauded this development and called for legal change to encourage it (Bebchuk 2005), while others are skeptical of activist investors and want to limit their ability to intervene (Bainbridge 2006).

Another key development has been the growing emphasis on the role of outside, independent directors (Fairfax Ch. 10). In the paradigmatic managerialist company of the post-war decades, most directors were inside managers or otherwise tied to the company (e.g., as company counsel or investment bankers). The board was nominally the source of legal authority in the corporations, but in fact it was not very important. Both best practice and the law have over the last few decades led to our current situation, where most public corporation directors are now outsiders with no significant ties to the company beyond their position on the board. Multiple studies consider what effect, if any, this has had on corporate actions.

While the above developments have been mostly of interest to those who specialize in corporate law and governance, the explosion in executive compensation is a trend that has received much public attention. Economists and legal scholars have explored this trend thoroughly 
(Walker Ch. 13). Some see this trend as reflecting optimal contracting, with new forms of compensation contracts giving executives better incentives to look after shareholder interests (Core et al. 2003). Others see the trend as reflecting managerial power, with the result that it often leads to worse, not better, incentives (Bebchuk \& Fried 2004).

Another trend in both corporate governance and law has been a growing focus on the role of a variety of gatekeepers. These are professionals who act as informational and reputational intermediaries. They gather information about companies, and help to warrant to outsiders the validity of information made public. Gatekeepers who are doing their jobs properly can thus help prevent managerial misbehavior. The legal responses to the two great financial crises of the past decade heavily implicate gatekeepers: much of the Sarbanes-Oxley Act focuses on a variety of gatekeepers, and the corporate governance elements of the Dodd-Frank Act also cover several types of gatekeepers. Important gatekeepers include corporate lawyers (Painter Ch. 14), rating agencies (Darbellay \& Partnoy Ch. 15), auditors and accountants (Cunningham Ch. 16), securities analysts (Fisch Ch. 17), D \& O insurers (Griffith Ch. 18), and investment banks (Frankel Ch. 19).

Mention of Sarbanes-Oxley and Dodd-Frank points to another key legal development: the federalization of important parts of corporate law. American corporate law scholars have traditionally focused on state law. A much discussed question has long been whether competition between states for corporate charters leads to a race to the bottom (Cary 1974) or to the top (Romano 1993). But now, important scholarship suggests that Delaware's main competition is not other states but rather the federal government (Roe 2003, 2005). Much debate swirls over both the nature of the federal-state interaction and whether or not it tends to lead to better or worse law (Ahdieh Ch. 20).

A final notable development in practice is globalization. American business and law firms are increasingly global in nature, and hence must care about the rules of other countries. The corporate laws of the leading industrial countries (Europe, Japan) are of most importance, but with the growth of emerging markets other countries are becoming important too, with China as the most obvious example. Corporate law scholarship has not ignored this development, and there has been much writing on comparative corporate governance (Clarke Ch. 21).

The above refers to notable developments in the law and the practice of corporate governance, which have been reflected in legal scholarship that analyzes their significance. That is, the scholarship of law and economics has changed as the law has changed. It has also changed as economics has changed. The remaining most notable developments in corporate legal scholarship reflect developments within economics scholarship.

One area where there has been less significant development over the last two decades within economics than one might expect is the theory of the firm. A significant exception is the work of Rajan and Zingales (1998) on the allocation of power within firms. Within legal scholarship there has been some significant evolution as two new broad theoretical approaches appeared, drawing upon both older and newer theories of the firm. The director primacy theory of Stephen Bainbridge (Ch. 2) draws upon the work of Kenneth Arrow (1974). It stresses the central role of the board of directors, and while Bainbridge describes a tradeoff between authority and accountability, he generally comes down on the side of board authority. The team production theory of Margaret Blair and Lynn Stout (Blair Ch. 3) moves the focus away from agency theory and instead draws more upon team production economic models, including both older (Alchian \& Demsetz 1972) and newer (Rajan \& Zingales 1998) models. 
A pronounced trend within economics over the last few decades has been a greater emphasis on empirical work. Legal scholars have followed that trend, with a lag. Much of the most visible and influential corporate law scholarship today involves econometric examination of data bases. This is true for many topics, but areas of particular concentration include studies of shareholder lawsuits (Thomas \& Thompson Ch. 9), the effect of outside directors (Fairfax Ch. 10), shareholder activism (Ferri Ch. 11), executive compensation (Walker Ch. 13), the effect of various gatekeepers (Fisch Ch. 17; Griffith Ch. 18), and the law and finance literature within studies of comparative corporate governance (Clarke Ch. 21).

Economic theory in recent decades has made important moves away from the old Chicago School story of well-functioning markets. Those moves came in two main steps. First, scholars such as Joseph Stiglitz (2002) developed the theory of asymmetric information. If market participants lack complete information about the relevant good or service, and if persons on one side of a transaction have more information than the other, then traditional conclusions as to the efficiency of markets become suspect and complicated. Asymmetric information certainly characterizes the relationship between corporate insiders and shareholders of public corporations, and so this theory has had an important effect on corporate law scholarship. Scholars like Lucian Bebchuk (2005) have used this theory to develop reasons why shareholders may need more regulatory protection than most participants in the first wave of corporate law and economics advocated.

The second step away from the Chicago School came with the development of behavioral economics. Behavioral economics, starting with the important experiments and insights of Tversky and Kahneman (1974), called into question the assumption of rational behavior that underlies neoclassical economics. As applied within the theory of finance, this movement has focused on various theoretical and empirical challenges to the efficient capital market hypothesis (Shleifer 2000). Applied within corporate law scholarship, behavioral finance has provided more arguments to question the efficiency of unregulated markets (Langevoort $\mathrm{Ch}$. 23), although behavioralist arguments further complicate matters by providing new insights into ways that government may fail as well.

We mention one other influential development in economics which has affected recent corporate law scholarship, although of course there are many more that we lack space to consider here. Economists have begun to focus more on comparison of economic institutions across countries. A particularly influential strand has been the law and finance literature (La Porta et al. 1997), although there have been other strands as well within a broad development of comparative institutional analysis (Aoki 2001). This literature has informed the large growth within law schools of writing on comparative corporate governance (Clarke Ch. 21).

Where will the economic analysis of corporate law go from here? Who are we to say? If we were good at anticipating that sort of thing, our lives would probably look different. The dominant development as we write is an ongoing reaction to the recent financial crisis. To a large extent the main legal developments have (appropriately) been in the different albeit related field of banking law and financial regulation. However, securities and corporate law have not been unaffected. The Dodd-Frank Act has many provisions affecting these fields, including the regulation of derivatives, hedge funds, credit rating agencies, executive compensation, and proxy access.

These regulations, and the crisis itself, have brought a new concern to the fore: systemic risk. Some financial markets are subject to bouts of excessive optimism followed by panics which can have severe consequences for the economy as a whole, especially where excessive 
leverage becomes widespread. Decisions by individual companies and investors may ignore the impact they have on these waves of optimism and panic: systemic risk is thus a type of externality. Corporate and securities law scholars in the past have paid little attention to this issue, but that has begun to change in the wake of the crisis (Schwarcz 2008). This will require drawing upon scholarship on the theory of networks (Cohen \& Havlin 2010) and complex evolving systems (Arthur et al. 1997).

We also suspect we may see more scholarship in an area that crosses two of the trends from economics discussed above. We have already seen a large growth in empirical scholarship, and also much research in both behavioral economics and behavioral finance. Some ideas from behavioralism can be explored well using regressions, the traditional empirical tool of economics. However, other ideas may be better explored using a range of other empirical tools, such as experiments, surveys, interviews, case studies, and participant-observer studies. In this exploration, the large existing literature on organizational behavior (Greenberg \& Baron 2007) is a resource that has probably been under-used by corporate law scholars.

\section{OVERVIEW OF THIS BOOK}

We have divided this book into five parts. Part I lays out the core constituency groups who are involved in a corporation and hence are most centrally affected by corporate law. Parts II and III explore the main governance rules and accountability mechanisms which are at the heart of corporate law. Part II considers mechanisms which give power to inside constituents, mainly directors, shareholders, and officers. Part III considers a variety of other corporate gatekeepers. Part IV looks at corporate law in different jurisdictions, including American states, the federal government, and different national governments. Part V looks at a few new theoretical developments.

\section{Part I: Corporate Constituencies}

Part I considers the core constituencies at the heart of the corporation, including directors, officers, shareholders, creditors, and employees, as well as the role (or lack thereof) of the interests of the public at large. It starts with Stephen Bainbridge's (Ch. 2) elaboration of his influential theory of director primacy. This theory attempts to both explain and defend the broad grant of authority to boards of directors that is at the heart of American corporate law. Drawing heavily on Arrow (1974), it argues that this grant of authority is essential to ameliorating the informational demands a large corporation faces. The grant of authority, however, creates the potential for abuse of that authority, creating a need for accountability mechanisms to limit such abuses. The tradeoff between authority and accountability is at the heart of corporate law. Bainbridge argues, though, that a presumption should generally favor authority, and he opposes most proposals to increase shareholder power. In his chapter Bainbridge lays out the basic logic of his position, and also responds to some criticisms of that position.

A leading competitor to director primacy is the team production theory of Margaret Blair and Lynn Stout (1999). Blair (Ch. 3) explicates this theory in her contribution to this volume. Like director primacy, team production theory defends the broad grant of authority to boards. However, it draws upon a different theoretical framework in doing so. The team production 
problem arises when multiple parties must contribute to the production process. One very useful solution to this problem involves a mediating hierarch with ultimate authority to direct production decisions and to mediate the conflicting preferences of the different parties. Although Blair and Stout agree with Bainbridge on the desirability of granting significant authority to boards, they disagree on the proper ultimate aims of the board in exercising that authority. Bainbridge believes boards should focus on maximizing the value of the corporation for shareholders. Blair and Stout believe boards should focus on maximizing the net value created for all corporate constituencies collectively.

The leading broad opposition to these approaches which defend broad board authority comes from proponents of shareholder primacy, with Lucian Bebchuk (2005) as the most prominent example. In his chapter Gordon Smith (Ch. 4) examines the role of shareholders in the modern American public corporation. He starts with the Berle and Means (1932) problem of the separation of ownership and control, but notes that the rise of institutional investors has changed the situation. Shareholders have three main sets of rights through which they can protect themselves: the right to vote, to sell, and to sue. Each of these rights has evolved significantly in recent years. Smith describes some of the changes and debates, and also briefly addresses the question of the proper beneficiaries of corporate decisions.

In his chapter, Charles Whitehead (Ch. 5) examines a corporate constituency that has received less, but increasing, attention: creditors. Not only do creditors provide an important source of financing, but they also play a significant role in corporate governance. Particularly important are covenants within debt agreements. Whitehead traces how corporate debt markets have become increasingly liquid, with the growth of syndication, securitization, and derivatives. This increased liquidity creates challenges for traditional means of monitoring and governance. Traditionally, banks with long-term relationships with creditor corporations were able to use private information to monitor and affect behavior. More liquid markets have weakened those ties, but created new potential governance mechanisms through the use of public signals such as the price of debt on the secondary market or credit ratings.

Another major corporate constituency that usually receives little attention in American law and scholarship is employees. Matthew Bodie (Ch. 6) analyzes their role within corporations. He notes that although employees have almost no formal role within American corporate law, they are a quite significant part of the subject matter of the economic theory of the firm. He analyzes how other areas of the law help shape the relationship between employees and the corporations for which they work, including agency law, intellectual property law, tax law, and employment law. He suggests that corporate law might provide a larger role for employees, but notes that as the traditional large corporation/long-term employee relationship rapidly evolves, laws and scholarly understandings will need to adapt in response.

Part I concludes with Ian Lee's (Ch. 7) examination of the role of the public interest in corporate law. This reviews the ongoing debate between shareholder primacy versus stakeholder conceptions of the corporation and the progressive critique of traditional law and economic theories which put shareholder interests first. The conventional view defends shareholder primacy by arguing that shareholders are the residual claimants of a corporation, and hence in need of special protection. Lee considers what he calls 'public facility' and 'powerful institution' critiques of this position. He then considers various proposals for expanding the role of the public interest in corporate law. These include modifying the board's mandate, non-shareholder board representation, using corporate law to control externalities, and encouraging socially responsible shareholder engagement. 


\section{Part II: Insider Governance}

Part II examines various mechanisms by which some of the insider constituencies discussed in Part I help to monitor and deter misbehavior by corporate officers and directors. Perhaps the leading such mechanism within state corporate law is the existence of fiduciary duties enforceable by shareholder suits. Claire Hill and Brett McDonnell (Ch. 8) discuss the evolution in recent decades of the law of fiduciary duty. Traditionally, fiduciary duties came in two varieties, the duty of loyalty, which applied to conflicts of interests, and the duty of care, which very rarely led to liability given the protection of the business judgment rule. A variety of intermediate standards of review and doctrines have arisen in Delaware law, which the cognoscenti will recognize in the shorthand of case names such as Unocal, Revlon, Zapata, Blasius, Caremark, and Disney. We argue that these represent an attempt by the courts to address concerns about structural bias in a variety of contexts where we expect directors to not be fully motivated to pursue the best interests of shareholders, while still granting boards the wide discretion that is a core element of American corporate law.

Randall Thomas and Robert Thompson (Ch. 9) provide an overview of the growing empirical literature on shareholder litigation under both federal securities law and state corporate law. Such suits are an important part of the enforcement scheme of both securities and corporate law, but there has been much concern about plaintiff lawyer abuse in shareholder litigation. For Delaware state law suits, class actions in the context of an acquisition have become the dominant form of litigation - a type of situation in which judicial oversight has been seen as critically needed. Studies suggest that litigated deals have higher premia, although it is not clear whether the reason is the litigation or the independent committees of directors typically formed in such transactions. In studies of federal cases, much attention has focused on the effects of the Private Securities Litigation Reform Act of 1995, with scholars reaching varied conclusions. Some studies suggest that some provisions of this Act have improved results for plaintiffs, while others find little effect.

One striking change in recent decades has been a strong emphasis on using outside, independent directors as monitors of corporate actions. Much scholarship has focused on whether outside directors are in fact able to act independently and improve corporate performance. Lisa Fairfax (Ch. 10) reviews the evidence in her chapter. She finds that the empirical evidence is mixed and, on the whole, does not show that boards with more outside directors are more effective at monitoring. Many factors limit the effectiveness of outside directors as monitors, including structural bias, selection bias, informational asymmetries, and a lack of legal liability as a spur. She argues for a larger role for both inside directors and external oversight.

Another striking change has been the growth of institutional investors and a related move towards increasing shareholder activism. There has been much debate over the effectiveness of that activism and whether or not it should be encouraged. In his chapter, Fabrizio Ferri (Ch. 11) reviews the empirical evidence on the effects of some kinds of shareholder activism. He focuses on what he calls 'low-cost' activism, as contrasted with 'activism via large ownership' in which a shareholder gains a large equity stake. Ferri looks particularly at two activism tools: director elections and shareholder proposals under Rule 14a-8. There is some evidence that vote withholding campaigns in board elections have reduced agency costs. A future development of potential significance is new rules on proxy access; event studies on the effect of the adoption of proxy access on share prices have been mixed. Early evidence on shareholder proposals suggested they were a weak governance mechanism. More recently 
they have become a more powerful tool, with their effect depending upon the degree of voting support they receive.

A governance mechanism that received much attention in early corporate law and economics scholarship was the market for corporate control (Manne 1965). The threat and reality of hostile takeovers was supposed to act as a significant deterrent to managerial misbehavior. However, the legal and institutional landscape for takeovers has changed greatly in recent decades, and scholarship has had to react to those changes. Steven Davidoff's chapter (Ch. 12) surveys that reaction. The main thrust of early scholarship was that takeovers and the threat thereof enhanced shareholder value, and hence the law should discourage takeover defenses. For the most part, courts and legislators have not followed that advice. Scholars have had to react to that fact. Reaction has been mixed. Some argue that takeovers remain viable, albeit in changed forms. Others argue that the law has gone too far in allowing defenses and should be reformed. Yet others argue that other accountability mechanisms have taken the place of the market for corporate control. Davidoff argues that takeover theory should become more nuanced, recognizing the greater complexity of modern capital markets and corporate governance practices.

One of the most publicly debated developments in corporate governance has been the explosion of executive compensation, due mainly to the growth in use of options and other forms of equity-based compensation. David Walker (Ch. 13) surveys the scholarly debate. There are two basic positions. One holds that equity compensation represents an efficient approach to align the incentives of corporate officers with the interests of shareholders. The other holds that increased compensation is a sign that officers have captured boards. Walker surveys studies of the amount of compensation, its design, and the impact of tax and accounting rules. He examines various reform attempts and proposals, including changes in board structure, disclosure, compensation consultants, and shareholder say on pay. Walker finds that executive pay is complex, and that each of the opposing theoretical approaches sheds significant light on elements of that pay.

\section{Part III: Gatekeepers}

A major development within corporate practice has been the increased prominence of a variety of corporate gatekeepers. The two main federal legislative developments of the past decade, Sarbanes-Oxley and the corporate governance elements of Dodd-Frank, have focused heavily on these gatekeepers. Part III contains chapters analyzing the role of six different sets of gatekeepers. The first of these is Richard Painter's (Ch. 14) chapter on business lawyers. Painter considers three different accounts of business lawyers within legal scholarship. Some describe lawyers as 'transaction cost engineers' who help increase the net value of transactions by allocating risk to those best able to evaluate and bear it. Others describe them as 'loophole engineers' who help clients get around the law. Yet others describe them as 'gatekeepers' who help certify their clients as suitable for interaction; Sarbanes-Oxley section 307 focused on this gatekeeping role. Each role helps explain aspects of what business lawyers do. Painter observes that as we learn more about the role lawyers played in the financial crisis, the next question will be whether they should have a legal or moral responsibility to behave differently.

Credit rating agencies played a central role in the growth of securitization, and their poor performance during the financial crisis made them a major target for criticism and for legal 
reform in the Dodd-Frank Act. Aline Darbellay and Frank Partnoy (Ch. 15) analyze their role and that reform. Traditionally, theorists understood credit rating agencies as informational intermediaries, but Darbellay and Partnoy argue that they are now better understood as providing 'regulatory license' due to the key role that ratings have played in many financial regulations. They review research on the potential for changes in regulatory oversight, increasing accountability through liability, and reduced regulatory reliance on ratings. They argue that Dodd-Frank contains some potentially beneficial reforms, but much will depend upon how the Act is implemented and more remains to be done.

Lawrence Cunningham (Ch. 16) reviews developments in the scholarship of law and accounting. Modern finance theory has greatly affected the understanding of accounting. Finance theory helped encourage the adoption of forward-looking disclosure in federal securities regulation. Cunningham argues that on balance this has helped reduce agency costs. Finance theory has also helped re-shape accounting standards, including those applicable to cash flow statements and fair value measures. Within state corporate law, finance theory has helped shape how and when court-ordered appraisals will be done. Finance and agency theory pointed to a role for outside auditors in helping monitor corporations, a role which became the focus for many reforms in the Sarbanes-Oxley Act of 2002.

Jill Fisch (Ch. 17) examines the role and regulation of another gatekeeper, the research analyst. Sarbanes-Oxley, along with the global research settlement between ten investment banks, the SEC, the New York Attorney General, and several others, instituted reforms which attempt to keep research analysts independent from the investment bankers who often work at the same firm. Research suggests that these reforms have led to reduced analyst coverage. Analyst recommendations have become less optimistic, with fewer buy recommendations, but they have also become less informative. The push for independence has put serious pressure on the business model for the research analyst industry.

Sean Griffith (Ch. 18) examines the role of providers of directors and officers (D \& O) insurance. This insurance may decrease the deterrence effect of insurance litigation, insofar as it prevents individuals from being personally liable. On the other hand, D \& O insurers may themselves play a role in monitoring corporate governance, since premia should depend upon how vulnerable a company is to suits. Griffith reviews empirical evidence on D \& O insurance, and suggests that the pricing of governance risk in insurance policies does not make up for the decrease in deterrence effect of such insurance. The evidence also suggests that selective payment of claims also does little to re-create a deterrence effect. Griffith suggests some policy reforms that could help strengthen deterrence, including disclosure of D \& O policy details or of settlement details.

Tamar Frankel (Ch. 19) considers the influence of investment banks on corporate governance. Corporate finance has become an increasingly large and influential industry, and this has affected corporate governance. Investment banks have played an important role in the rise of finance. They provide an array of services, including underwriting, securities trading, advising on mergers and acquisitions, and asset management. In providing these services, they have played a major role in advising and influencing corporate management.

\section{Part IV: Jurisdiction}

Competition between states for charters has long been a major topic within corporate law scholarship. Robert Ahdieh (Ch. 20) surveys recent developments in the scholarship of corpo- 
rate law federalism. The traditional literature focused on the relationship between states, and asked whether the ability to choose one's state of incorporation tends to lead to a race to the bottom or to the top. Ahdieh argues that to a large extent this debate recapitulates an underlying debate concerning more basic assumptions about how well capital markets constrain managers. He suggests that state competition, however, can plausibly be seen as a check on regulatory abuse. The most dramatic element in recent scholarship is an emphasis on the vertical element of federalism, with the federal government a leading player. Here too, much of the debate as to the value of the federal role turns on differences as to whether mandatory rules are needed, or whether choice among rules is better. Scholarship now must focus on the relationship between actors at different levels of the federal scheme and on achieving an optimal balance between state and federal roles.

Donald Clarke (Ch. 21) surveys comparative corporate governance (CCG) scholarship. CCG scholarship has used a variety of methodologies, but Clarke characterizes, and to some extent criticizes, functionalism as the prevailing methodology. An important more recent methodological trend, seen particularly in the law and finance literature (La Porta et al. 1997), has been quantitative empirical studies using standardized measures of corporate governance. Clarke describes some important lessons learned from CCG, including the extent to which economics, law, history, politics, culture, and property rights matter in shaping corporate governance. Clarke concludes by describing major challenges facing CCG scholarship. The vast literature on whether or not national systems are converging to the same model of corporate governance may have reached its useful limits. In contrast, CCG scholars could usefully pay more attention to topics such as non-corporate forms and law and practice in emerging countries like China and India. CCG scholars should also take into account that countries differ in their view of what corporate governance is trying to accomplish - they should be less quick to assume that all laws should be judged by how well they handle the type of agency problems on which American scholars focus.

\section{Part V: New Theory}

Recent economic theory has given a twist on the concept of agency costs with the idea of tunneling, namely that managers and controlling shareholders can extract (tunnel) wealth from firms using a variety of methods. Vladimir Atanasov, Bernard Black, and Conrad Ciccotello (Ch. 22) analyze how effectively US rules limit tunneling in public corporations. They categorize tunneling into three types. In cash flow tunneling, insiders extract current cash flow. In asset tunneling, insiders buy corporate assets at below-market prices, or sell assets to the corporation at above-market prices. In equity tunneling, insiders acquire equity at below-market prices. They examine how many kinds of rules, including corporate, securities, accounting, tax, and creditor protection, affect each of these kinds of tunneling. Such a broad perspective is necessary, because to the extent that these rules collectively constrain some forms of tunneling well but not others, insiders will tend to gravitate to less-constrained forms.

Donald Langevoort (Ch. 23) explores how ideas from behavioral economics and finance have affected corporate law scholarship. Behavioral economics uses ideas from psychology to modify standard economic assumptions about the rationality of individual behavior. A crucial question for applying such ideas within corporate law is why persons behaving closer to the standard assumptions of rationality are not able to drive others out of the market, given 
the large amounts of money at stake and the competitiveness of financial markets. Langevoort suggests that in some cases, some sorts of heuristics have adaptive value. He surveys how scholars have applied the psychological literature to study board behavior and to question the efficient markets hypothesis.

Ronald Gilson and Reinier Kraakman (Ch. 24) examine what remains of the efficient market hypothesis in the wake of the financial crisis. While many have proclaimed that the crisis has discredited the hypothesis, Gilson and Kraakman argue that properly conceived the hypothesis remains viable. They distinguish informational and fundamental efficiency, acknowledging that the distinction is hard to put into practice. Efficiency should be conceived as a relative concept, with markets more or less efficient depending upon the costs to market participants of obtaining and effectively using information. The financial crisis revealed that those costs were quite high in some important markets. The efficient market hypothesis can help guide policy by pointing to measures that may help reduce those informational costs, thereby improving market efficiency.

\section{ACKNOWLEDGMENTS}

Many people have helped make this project possible. We would like to thank some of them here. First of course is each of the contributors. We also thank Francesco Parisi and Judge Richard Posner, the editors of the overall Research Handbooks in Law and Economics series, for asking us to compile this volume.

The good people at Edward Elgar have also been indispensable. Tara Gorvine has been our main contact, and she has provided assistance and advice repeatedly at each stage of the project. Rebecca Wise did great work in copyediting the volume.

At the University of Minnesota, Julie Hunt, Bria Goldman and Alia El Bakri provided exceptional administrative assistance. Suzanne Thorpe and other staff at the Law Library provided wonderful help on several chapters. Jamie Kastler provided excellent research assistance on our own chapter. Our dean, David Wippman, provided summer research funding which helped us work on the volume.

Last on the page but first in our hearts, we thank our partners, Eric Hillemann (Hill) and Paul Rubin (McDonnell), for all the emotional and household support that gave us the time and energy to get this done.

\section{REFERENCES}

Alchian, Armen A. \& Harold Demsetz (1972), 'Production, Information Costs, and Economic Organization', American Economics Review, 62, 777-795.

Aoki, Masahiko (2001), Towards a Comparative Institutional Analysis, Boston: MIT Press.

Arrow, Kenneth J. (1974), The Limits of Organization, New York: W.W. Norton \& Co.

Arthur, W. Brian, Steven N. Durlauf \& David A. Lane (1997), The Economy as a Complex Evolving System II, Reading, Mass.: Addison-Wesley.

Bainbridge, Stephen M. (2006), 'The Case for Limited Shareholder Voting Rights', UCLA Law Review, 53, 601-36. Bebchuk, Lucian A. (2005), 'The Case for Increasing Shareholder Power', Harvard Law Review, 118, 833-914.

Bechuk, Lucian A. \& Jesse Fried (2004), Pay Without Performance: The Unfulfilled Promise of Executive Compensation, Boston: Harvard University Press.

Berle, Adolf A. \& Gardiner C. Means (1932), The Modern Corporation and Private Property, New York: Commerce Clearing House, Inc. 
Blair, Margaret M. \& Lynn A. Stout (1999), ‘A Team Production Theory of Corporate Law', Virginia Law Review, $85,247-328$.

Cary, William L. (1974), 'Federalism and Corporate Law: Reflections Upon Delaware', Yale Law Journal, 83, 663-705.

Coase, Ronald H. (1937), 'The Nature of the Firm', Economica, 4, 386-405.

Cohen, Reuven \& Shlomo Havlin (2010), Complex Networks: Structure, Robustness, and Function, Cambridge: Cambridge University Press.

Core, John E., Wayne R. Guay \& David F. Larcker (2003), 'Executive Equity Compensation and Incentives: A Survey', FRBNY Economic Policy Review, 9, 27-50.

Easterbrook, Frank \& Daniel Fischel (1991), The Economic Structure of Corporate Law, Boston: Harvard University Press.

Farber, Daniel A. \& Anne Joseph O'Connell (2010), 'Introduction: A Brief Trajectory of Public Choice and Public Law', in Daniel A. Farber \& Anne Joseph O'Connell, Research Handbook on Public Choice and Public Law, Northampton, Mass.: Edward Elgar.

Greenberg, Jerald \& Robert A. Baron (2007), Behavior in Organizations, 9th ed., New York: Prentice Hall.

Grossman, Sanford J. \& Oliver D. Hart (1986), 'The Costs and Benefits of Ownership: A Theory of Vertical and Lateral Integration', Journal of Political Economy, 94, 691-719.

Hart, Oliver (1995), Firms, Contracts, and Financial Structure, Oxford: Oxford University Press.

Hart, Oliver D. \& John Moore (1990), 'Property Rights and the Nature of the Firm', Journal of Political Economy, 98, 1119-58.

Jensen, Michael C. \& William H. Meckling (1976), 'Theory of the Firm: Managerial Behavior, Agency Costs, and Ownership Structure', Journal of Financial Economics, 3, 305-60.

La Porta, Rafael, Florencio Lopez-de-Silanes, Andrei Shleifer \& Robert Vishny (1997), 'Legal Determinants of External Finance', Journal of Finance, 52, 1131-1150.

Manne, Henry G. (1965), 'Mergers and the Market for Corporate Control', Journal of Political Economy, 73, 110-20.

Manne, Henry G. (1967), 'Our Two Corporation Systems: Law and Economics’, Virginia Law Review, 53, $259-284$.

Rajan, Raghuram G. \& Luigi Zingales (1998), 'Power in the Theory of the Firm', Quarterly Journal of Economics, $113,387-432$.

Roe, Mark J. (2003), 'Delaware's Competition', Harvard Law Review, 117, 588-646.

Roe, Mark J. (2005), 'Delaware's Politics', Harvard Law Review, 118, 2491-2543.

Romano, Roberta (1993), The Genius of American Corporate Law, New York: AEI Press.

Schwarcz, Steven L. (2008), 'Systemic Risk', Georgetown Law Journal, 97, 193-249.

Shleifer, Andrei (2000), Inefficient Markets: An Introduction to Behavioral Finance, Oxford: Oxford University Press.

Stiglitz, Joseph E. (2002), 'Information and the Change in the Paradigm in Economics', American Economic Review, 460-501.

Tversky, Amos \& Daniel Kahneman (1974), 'Judgment Under Uncertainty: Heuristics and Biases', Science, 185, $1124-31$.

Williamson, Oliver E. (1975), Markets and Hierarchies: Analysis and Antitrust Implications, New York: The Free Press.

Williamson, Oliver (1985), The Economic Institutions of Capitalism, New York: The Free Press. 
Claire A. Hill and Brett H. McDonnell - 9781781005217 Downloaded from PubFactory at 04/26/2023 12:31:30PM 